\title{
Biological and Molecular Characterization of a Novel Carmovirus Isolated from Angelonia
}

\author{
Scott Adkins, John Hammond, Abed Gera, Clarissa J. Maroon-Lango, \\ Irena Sobolev, Andrea Harness, Mohammad Zeidan, and Sara Spiegel
}

\begin{abstract}
First author: U.S. Department of Agriculture, Agricultural Research Service (USDA-ARS), Fort Pierce, FL 34945; second and fourth authors: Floral and Nursery Plants Research Unit, USDA-ARS, Beltsville, MD 20705; third, fifth, and eighth authors: Department of Virology, Agricultural Research Organization, The Volcani Center, P.O. Box 6, Israel; sixth author: Agdia, Inc., Elkhart, IN 46514; and seventh author: The Plant Protection and Inspection Services, Ministry of Agriculture, Bet Dagan 50250, Israel.
\end{abstract} Accepted for publication 9 December 2005.

\section{ABSTRACT}

Adkins, S., Hammond, J., Gera, A., Maroon-Lango, C. J., Sobolev, I., Harness, A., Zeidan, M., and Spiegel, S. 2006. Biological and molecular characterization of a new carmovirus isolated from Angelonia. Phytopathology 96:460-467.

A new carmovirus was isolated from Angelonia plants (Angelonia angustifolia), with flower break and mild foliar symptoms, grown in the United States and Israel. The virus, for which the name Angelonia flower break virus (AnFBV) is proposed, has isometric particles, $\approx 30 \mathrm{~nm}$ in diameter. The experimental host range was limited to Nicotiana species, Schizanthus pinnatus, Myosotis sylvatica, Phlox drummondii, and Digitalis purpurea. Virions were isolated from systemically infected $N$. benthamiana leaves, and directly from naturally infected Angelonia leaves, using typical carmovirus protocols. Koch's postulates were completed by mechanical inoculation of uninfected Angelonia seedlings with purified virions. Isometric particles were observed in leaf dips and virion preparations from both Angelonia and $N$. benthamiana, and in thin sections of Angelonia flower tissue by electron microscopy. In sodium dodecyl sulfate-polyacrylamide gel electrophoresis of dissociated purified virus preparations, a major protein component with a molecular mass of $38 \mathrm{kDa}$ was observed. Virion preparations were used to produce virusspecific polyclonal antisera in both Israel and the United States. The antisera did not react with Pelargonium flower break virus (PFBV), Carnation mottle virus (CarMV), or Saguaro cactus virus ( $\mathrm{SgCV}$ ) by either enzyme-linked immunosorbent assay or immunoblotting. In reciprocal tests, antisera against PFBV, CarMV, and SgCV reacted only with the homologous viruses. The complete nucleotide sequence of a Florida isolate of AnFBV and the coat protein (CP) gene sequences of Israeli and Maryland isolates were determined. The genomic RNA is 3,964 nucleotides and contains four open reading frames arranged in a manner typical of carmoviruses. The AnFBV CP is most closely related to PFBV, whereas the AnFBV replicase is most closely related to PFBV, CarMV, and $\mathrm{SgCV}$. Particle morphology, serological properties, genome organization, and phylogenetic analysis are all consistent with assignment of AnFBV to the genus Carmovirus.

Additional keywords: host range, purification, serology.
Angelonia angustfolia (Scrophulariaceae) is a popular warmseason annual sub-shrub originating in Central and Latin America (23). It has enjoyed a renewed interest from growers and consumers due to the development of several new cultivars with attractive flowers in a variety of colors. Angelonia is most often grown as an annual bedding plant, but may survive winters; it is excellent for use in the landscape and in large containers, and is becoming more popular for cut flowers (23). This vegetatively propagated plant was recently introduced into Israel by importing cuttings from Europe and the United States.

During surveys for viral diseases conducted in the United States and Israel, Angelonia plants grown in commercial nurseries and garden centers were observed with flower break and mild foliar symptoms. Here, we report the purification and characterization of a new carmovirus referred to as Angelonia flower break virus (AnFBV) isolated from Angelonia. We also report the cloning and sequencing of the viral genome and its comparison to the published sequences of other carmoviruses.

Corresponding author: S. Adkins; E-mail address: SAdkins@ushrl.ars.usda.gov

DOI: 10.1094/PHYTO-96-0460

This article is in the public domain and not copyrightable. It may be freely reprinted with customary crediting of the source. The American Phytopathological Society, 2006

\section{MATERIALS AND METHODS}

This research was completed in three laboratories: the U.S. Department of Agriculture-Agricultural Research Service (USDAARS) in (i) Fort Pierce, FL, and (ii) Beltsville, MD, and (iii) the Department of Virology, Agricultural Research Organization, The Volcani Center, Israel. Similar methods were followed in all laboratories unless specified otherwise in the text.

Virus source, host range, and transmission. Leaf samples of symptomatic Angelonia grown in commercial greenhouses and/or outdoors in the United States and Israel were examined for virus infection using electron microscopy and commercially available virus group specific (degenerate) primers (Agdia, Elkhart, IN) following the manufacturer's recommendations for reverse transcription-polymerase chain reaction (RT-PCR). Samples containing isometric particles and/or testing positive by RT-PCR with virus group specific primers were homogenized in $1 \%(\mathrm{wt} / \mathrm{vol})$ $\mathrm{K}_{2} \mathrm{HPO}_{4}$, or in $20 \mathrm{mM}$ sodium phosphate (pH 7.0), and the sap was used to inoculate leaves of Ageratum houstonianum (ageratum), Antirrhinum majus (snapdragon) cvs. Sonnet and Fordhook, Aquilegia vulgaris (columbine), Capsicum annum, Centaurea cyanus (bachelor's button), Chenopodium quinoa, C. amaranticolor, C. murale, Consolida ambigua (larkspur), Cucumis sativus, Cucurbita pepo, Datura stramonium, Digitalis purpurea (foxglove), Gomphrena globosa, Helenium hybrid (sneezeweed), Linum grandiflorum (flax), Lobelia erinus (lobelia), Lunaria 
annua (money plant, honesty), Lychnis coronaria (dusty miller), Lycopersicon esculentum, Lysimachia punctata (loosestrife), Myosotis sylvatica (forget-me-not), Nicotiana benthamiana, $N$. clevelandii, N. edwardsonii, N. glutinosa, N. megalosiphon, $N$. rustica, $N$. sylvestris, $N$. tabacum $\mathrm{cv}$. NN, $N$. tabacum cv. Samsun, N. tabacum cv. Samsun NN, N. tabacum Xanthi nc, N. tabacum cv. White Burley, Petunia hybrida, Phlox drummondii, Physalis alkakengi, P. floridensis, Polemonium caeruleum (Jacob's ladder), Raphanus sativus (Japanese radish), Salvia splendens (salvia), Saponaria ocymoides (trailing soapwort), Schizanthus pinnatus (butterfly flower), Verbascum phoenicum (purple mullein), and Vigna sinensis (cowpea). These plants were maintained in a greenhouse and observed for symptom development. Inoculated as well as upper, noninoculated leaves were tested by enzyme-linked immunosorbent assay (ELISA), RTPCR, or both 2 to 4 weeks after inoculation.

The green peach aphid (Myzus persicae (Sulz.)) was used for transmission tests. A clone of $M$. persicae that originated from a single female was reared on uninfected $R$. sativus plants. Nonviruliferous apterous aphids were allowed to feed for $5 \mathrm{~min}$ on naturally infected Angelonia. Five aphids were transferred to each of 20 uninfected Angelonia seedlings or $20 \mathrm{~N}$. clevelandii plants and allowed to remain on the test plants for $12 \mathrm{~h}$. These plants were then sprayed with insecticides, maintained in a greenhouse, observed for symptom development, and tested by ELISA 3 weeks postinoculation.

Pollen from uninfected or AnFBV-infected Angelonia plants was used to manually pollinate infected plants from which mature seeds were later collected. The presence of AnFBV in plants designated as seed sources was confirmed by ELISA prior to seed collection. Seeds were collected from uninfected plants to serve as controls. Seeds were washed in running tap water and dried at room temperature. Seeds were germinated and seedlings were subsequently transplanted to plastic pots in which they were grown for 5 to 8 weeks before being tested for AnFBV. Sixty-five seedlings were grown, observed weekly for AnFBV symptoms, and assayed by ELISA.

Virus purification. In Israel, virus was purified from naturally infected Angelonia, as described by Franck and Loebenstein (9), followed by sucrose gradient centrifugation (2). In Florida, virions were isolated from symptomless $N$. benthamiana leaves as described by Waterworth et al. (30). In Maryland, virions were isolated from $N$. benthamiana using a combination of methods based on polyethylene glycol concentration followed by high speed and $\mathrm{CsCl}$ gradient centrifugation $(11,16)$. Virus concentration was estimated spectrophotometrically with an extinction coefficient of $E_{260 \mathrm{~nm}}{ }^{0.1 \%}$ 1cm $=5$ for carmoviruses (3).

Production of antibodies. Antibodies against AnFBV were generated in female New Zealand white rabbits as described previously (32). The specificity of antisera was tested by western blot analysis (27), double-antibody sandwich ELISA (DASELISA) (7), antigen-coated plate indirect ELISA (12), and immunoelectron microscope (IEM) decoration test (17).

Physicochemical properties. The molecular mass $(\mathrm{Mr})$ of AnFBV coat protein (CP) was determined by sodium dodecyl sulfate-polyacrylamide gel electrophoresis (SDS-PAGE) of purified virus preparation using $12 \%$ polyacrylamide gels (10). For comparison, the $\mathrm{CP}$ of Pelargonium flower break virus (PFBV) was included. The protein bands were either stained with $0.1 \%$ (wt/vol) Coomassie brilliant blue or electroblotted to a nitrocellulose membrane (Bio-Rad, Richmond, CA) and probed with polyclonal antisera to AnFBV (this report) or PFBV, Saguaro cactus virus (SgCV), or Carnation mottle virus (CarMV) (produced at ARO, Volcani Center, Israel). Antibody binding was detected with anti-rabbit immunoglobulin $\mathrm{G}$ conjugated to alkaline phosphatase (BioMakor, Rehovot, Israel).

Electron microscopy. Crude plant extracts in $0.1 \mathrm{M}$ phosphate buffer or purified virus preparations were negatively stained with
$2 \%(\mathrm{wt} / \mathrm{vol})$ uranyl acetate or NaPTA (pH 7.0) and examined for virus with an electron microscope (JEOL 100CX II; JEOL Ltd., Tokyo, Japan). Particle diameter was measured on $\times 50,000$ enlarged photographs, and the mean diameter was calculated from the measurements of 100 particles.

For ultrathin sections, segments $(2 \times 1 \mathrm{~mm})$ were excised from young leaves of Angelonia and processed following Orion and Franck (19). Angelonia flower tissue was fixed in 3\% glutaraldehyde in $50 \mathrm{mM}$ Na cacodylate, $\mathrm{pH} 7.0$, and embedded and stained as described previously (14) except that cacodylate buffer was used throughout.

IEM decoration tests were conducted as described by Milne and Luisoni (17). For determination of the serological reactions of the virus with other carmoviruses, AnFBV antisera and each of the polyclonal antisera listed above were diluted 1:10 and tested. Homologous and heterologous decoration reactions were completed using antigen from crude extracts of infected plants.

RNA preparation and analysis. Viral RNA for cloning and sequencing of the genome was prepared essentially as described previously $(18,22)$. Alternatively, RNA was isolated from $\approx 100 \mu \mathrm{g}$ of purified virions with an RNeasy Plant Mini Kit (Qiagen, Valencia, CA) following the manufacturer's recommendation.

Viral-associated double-stranded (ds)RNAs were isolated from infected tissue by total nucleic acid extraction and subsequent partitioning on nonionic cellulose (CF 11, Whatman Inc., Florham Park, NJ) using a combination of previously described protocols $(13,28)$. Isolated dsRNAs were electrophoresed on a $1.5 \%$ agarose gel at 60 volts for $1.5 \mathrm{~h}$ and visualized by staining with ethidium bromide.

Total RNA for northern blot analysis was isolated from uninfected and AnFBV-infected $N$. benthamiana as previously described (6). About $5 \mu \mathrm{g}$ of each RNA sample was denatured in glyoxal and electrophoresed on a NorthernMax-Gly $1.2 \%$ agarose gel (Ambion, Inc., Austin, TX) at 60 volts for $2 \mathrm{~h}$. Electrophoresed RNAs were transferred to Nytran SuPerCharge membranes (Whatman Schleicher \& Schuell Bioscience, Florham Park, NJ) using the TurboBlotter kit (Whatman Schleicher \& Schuell Bioscience) following manufacturer's recommendations. Transferred RNAs cross-linked to the membrane were hybridized at $50^{\circ} \mathrm{C}$ with a digoxigenin (DIG)-labeled AnFBVCP polymerase chain reaction $(\mathrm{PCR})$ product generated using primers $5^{\prime} \mathrm{AnFBVCP}$ and 3'AnFBVCP described below.

cDNA synthesis and cloning. First-strand cDNA was synthesized by Moloney murine leukemia virus reverse transcriptase (Invitrogen, Carlsbad, CA) at $37^{\circ} \mathrm{C}$ for $60 \mathrm{~min}$ using oligo(dT) primer and standard methods (22). Second-strand cDNA was synthesized by the replacement synthesis method using a Superscript Double-Stranded cDNA synthesis kit (Invitrogen) according to the manufacturer's instructions. A second population of clones was prepared using primers derived from the initial population of clones, and RT-PCR by standard methods (22). Products from the initial cDNA synthesis reactions were ligated into the EcoRV site of pGEM-5Zf (Promega, Inc., Madison, WI), whereas those from the second population were ligated into pGEM-T (Promega). The $5^{\prime}$ terminus was amplified by random amplification of cDNA ends (RACE) using the specific AnFBV primer, 5'AnFBVRepvc (5'-GCCAACCGCAACGGCCCCTG-3'), with the Generacer (Invitrogen) $5^{\prime}$ primer. The $3^{\prime}$ terminus was amplified by RACE using the specific AnFBV primer, 3'AnFBVendv (5'-CGGCGACAGAGCAAGCGACG-3'), with the Generacer $3^{\prime}$ primer. The genomic sequence of the Florida AnFBV isolate was used to design primers flanking the deduced $\mathrm{CP}$ gene for amplification of the corresponding genomic region from the Israeli and Maryland virus isolates by RT-PCR. The viral-sense primer, 5'AnFBVCP (5'CCCACCGCTACTCAAACGAC-3'), was identical to nucleotides 2591 to 2610 just upstream of the $\mathrm{CP}$ initiation codon, and the viral complementary sense primer, 3'AnFBVCP (5'-GGGAAGA- 
GTCGTTGACCGGAAGC-3'), was complementary to nucleotides 3740 to 3762 just downstream of the $\mathrm{CP}$ stop codon. The $\mathrm{CP}$ PCR products of the Israeli and Maryland isolates were cloned into pCR2.1 using the TA Cloning Kit (Invitrogen).

Sequence analysis. Selected clones were sequenced on an automated sequencer (ABI3730XL) at the U.S. Horticultural Research Laboratory (USHRL) DNA Sequencing Support Laboratory. Sequences were edited in VectorNTI (InforMax, North Bethesda, MD) and subjected to BLAST searches (1). Overlapping clones were aligned manually and with ClustalX version 1.8 (25) to assemble the complete AnFBV genome. Putative open reading frames (ORFs) were identified by comparison to related genomes identified using BLASTX and with ORF Finder (National Center for Biotechnology Information).

Selected recombinant plasmids containing the $\mathrm{CP}$ genes of the Israeli and Maryland isolates were sequenced using the BigDye 3.1 Cycle Sequencing Kit (Applied Biosystems, Foster City, CA) and run on an Applied Biosystems 310 Genetic Analyzer (Hy Laboratories, Rehovot, Israel and Floral and Nursery Plant Research Unit, respectively). Multiple alignments of the $\mathrm{CP}$ genes and deduced proteins of the three AnFBV isolates and recognized carmovirus species were prepared using ClustalW version 1.82 (26). Percent nucleotide and amino acid identities were calculated using CLUSTALDIST. Phylogenetic analyses were performed using Phylip 3.6.4 (8). Bootstrap analyses were carried out with 1,000 replicates, and resulting trees were displayed with TreeView 1.6.6 (20).

\section{RESULTS}

Virus transmission and host range. Initially, AnFBV was detected by electron microscopy and/or RT-PCR in Angelonia plants that exhibited mild mottle symptoms on leaves (Fig. 1A and B) and overall stunting (Fig. 1A), accompanied by flower break (Fig. 1C). Only spherical particles were observed by electron microscopy, and RT-PCR products were only amplified with degenerate carmovirus primers. In further tests, the virus was also detected in symptomless Angelonia plants. All Angelonia plants with blue or dark blue flowers, representing the commercial stock grown in Israel and tested by electron microscopy and ELISA, were found to be infected. Similar symptoms were observed in the United States. Occasionally, mild green mottling in leaves developed when plants were exposed to high temperatures during the growing season.

Transmission of virus from Angelonia plants to the herbaceous host plants listed above resulted in obvious visible symptoms only in $N$. benthamiana. Systemic mild mottle and/or mild mosaic developed about 12 to 14 days after inoculation. These symptoms were often transient, with new growth frequently showing no obvious symptoms. Some infected plants, including $N$. clevelandii, developed a slight general chlorosis. No other viruses were detected by bioassay, supporting results from electron microscopy and virus group-specific PCR.

Testing of inoculated plants by electron microscopy, ELISA, and/or RT-PCR identified symptomless hosts; in some instances,
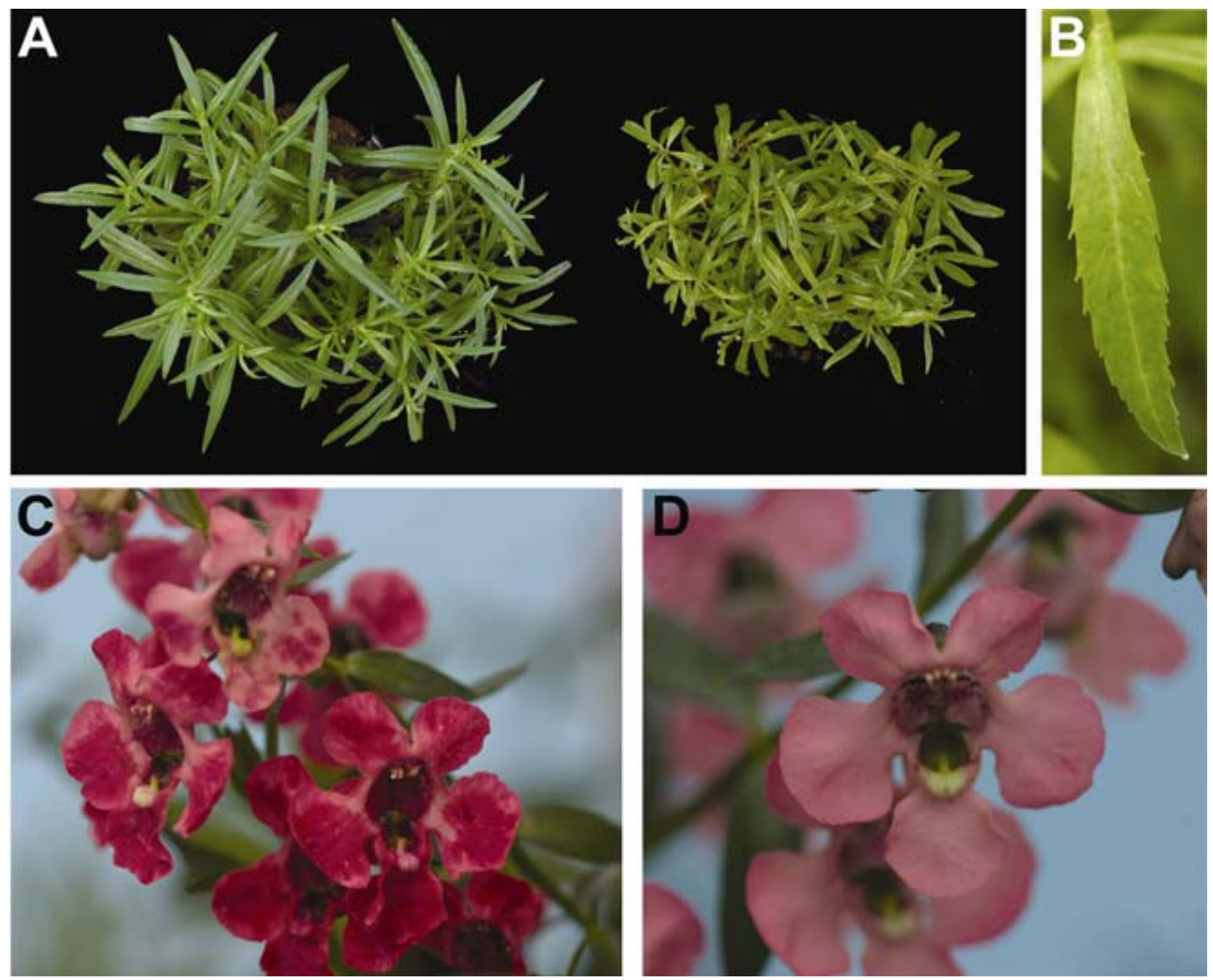

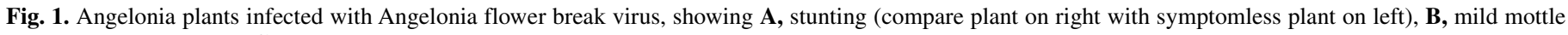
symptoms on leaves, and $\mathbf{C}$, flower break. D, A symptomless flower of the same cultivar is shown for comparison. 
results were confirmed by bioassay on $N$. benthamiana and then ELISA. Only a local infection was found in N. edwardsonii, $N$. rustica, $N$. sylvestris, $M$. sylvatica, and Digitalis purpurea. Local and systemic infection was confirmed in $N$. benthamiana, N. clevelandii, N. megalosiphon, Schizanthus pinnatus, and Phlox drummondii.

Uninfected Angelonia seedlings were mechanically inoculated with AnFBV virions isolated from infected Angelonia. The symptoms that developed on these mechanically inoculated plants were identical to those observed on the original, naturally infected Angelonia plants. AnFBV infection was confirmed by ELISA thus completing Koch's postulates.

No transmission of AnFBV by aphids occurred from naturally infected to uninfected Angelonia (0/20) or to $N$. clevelandii $(0 / 20)$. All leaf samples tested by ELISA were negative.

No visible symptoms were observed in Angelonia seedlings grown from seeds harvested from naturally infected AnFBV plants that were pollinated with pollen from either uninfected or infected plants. None of the seedlings were found to be infected with AnFBV as determined by ELISA (0/65), up to 8 weeks after germination. These results indicate that the virus is not efficiently seed transmitted in Angelonia.

Electron microscopy. Spherical isometric particles, $\approx 30 \mathrm{~nm}$ in diameter, were consistently observed in negatively stained samples from leaves of naturally infected Angelonia or systemically infected $N$. benthamiana (data not shown). Electron microscopy studies using ultrathin sections of infected Angelonia tissues revealed the presence of clusters of isometric particles, resembling virus particles, in the cytoplasm of leaf epidermal, mesophyll, and vascular parenchyma cells (data not shown) and flower petals (Fig. 2C); no viral inclusions were observed.

Virus purification, physicochemical and serological properties. Using the isolation procedures outlined above, highly purified virions were obtained both from leaves of naturally infected Angelonia and from mechanically inoculated $N$. benthamiana plants. When the virus was centrifuged in an isopycnic cesium chloride gradient, a single opalescent band was formed, from which highly purified virus was recovered following dialysis to remove cesium chloride. Yields of purified virus ranged from 50 to $60 \mathrm{mg} / \mathrm{kg}$ to about $300 \mathrm{mg} / \mathrm{kg}$ for infected Angelonia and $N$. benthamiana tissue, respectively. Electron microscopy revealed large numbers of virus particles with relatively little contamination (Fig. 2A and B). The virus particles gave a distinct decoration with the specific antisera produced against AnFBV (Fig. 2D). The $A_{260 / 280}$ was found to be 1.46 , uncorrected for light scattering. The reported $A_{260 / 280}$ ratio for carmoviruses is 1.50 to 1.60 (3).

Denaturing SDS-PAGE of SDS-disrupted purified virus preparations revealed one major polypeptide band with an estimated $\mathrm{Mr}$ of $38 \mathrm{kDa}$ (Fig. 3A, lane 2). Immunoblots with AnFBV antisera gave a clear and strong reaction with the $38-\mathrm{kDa}$ band and therefore it was identified as the AnFBV CP (Fig. 3B, lane 2).
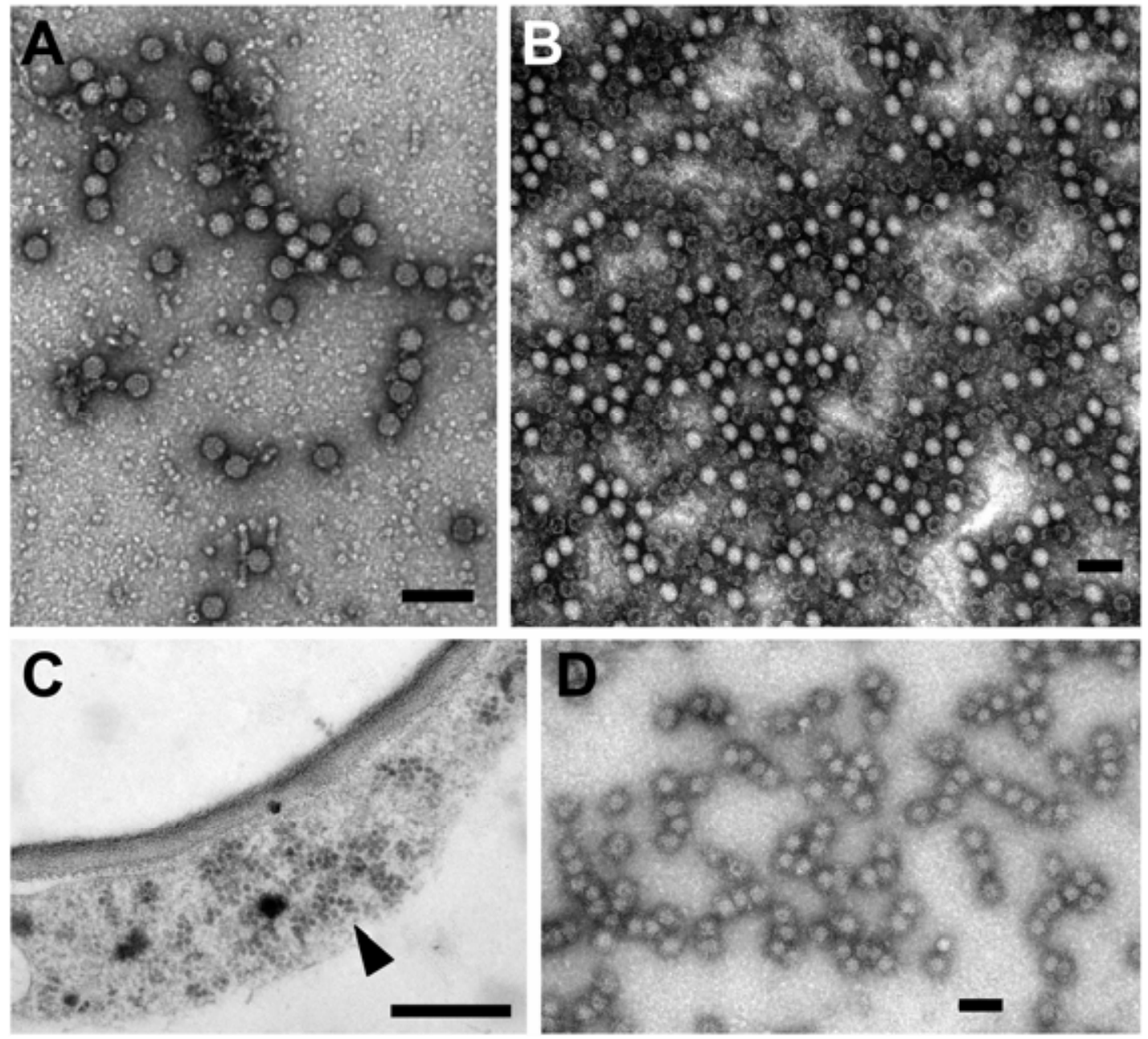

Fig. 2. Angelonia flower break virus (AnFBV) virion morphology is typical of recognized carmoviruses. A and B, Virion preparations resulting from typical carmovirus isolation protocols stained with $2 \%(\mathrm{wt} / \mathrm{vol})$ uranyl acetate and analyzed by electron microscopy. Mean particle diameter of 100 measured virions was $30 \mathrm{~nm}$. Scale bar represents $100 \mathrm{~nm}$. Similar results were obtained with A, Florida, B, Maryland, and D, Israeli isolates. C, Ultrathin section of Angelonia flower petal tissue showing AnFBV particles in the cytoplasm (particles are indicated by arrow). Scale bar represents $500 \mathrm{~nm}$. D, Immunodecoration of AnFBV virions with rabbit polyclonal antiserum prepared to AnFBV. Scale bar represents $50 \mathrm{~nm}$. 
In comparing the mobility of the AnFBV CP in SDS-PAGE with those of other carmoviruses, the estimated size of PFBV, CarMV, and $\mathrm{SgCV}$ was found to be 35,38 , and $39 \mathrm{kDa}$, respectively (data not shown). In reciprocal tests with PFBV, CarMV, and $\mathrm{SgCV}$ antisera in immunoblots, only homologous reactions were obtained (data not shown).

In ELISA tests, the reactions with AnFBV antiserum were highly specific and efficient in detecting the virus even when infected plant material was used at a dilution of 1:10,000. Average DAS-ELISA values $\left(\mathrm{OD}_{405}\right)$ of samples from naturally infected Angelonia, and mechanically inoculated $N$. benthamiana, $N$. clevelandii, and N. edwardsonii diluted 1:100, were $1.75 \pm 0.09,1.30 \pm$ $0.15,0.87 \pm 0.05$, and $0.65 \pm 0.03$, respectively. The antiserum did not cross-react with extracts from plants infected with the carmoviruses PFBV, CarMV, or SgCV.

dsRNA and northern blot analyses. dsRNA isolated from AnFBV-infected $N$. benthamiana plants and fractionated on an agarose gel showed four major bands (Fig. 4A, lane 2). The largest band, of about $4.0 \mathrm{kbp}$, co-migrated with the equivalent dsRNA of CarMV (Fig. 4A, lanes 1 and 3), and is considered the putative dsRNA form of the AnFBV genomic RNA. Three additional dsRNA species of about 1.75, 1.60, and $1.31 \mathrm{kbp}$ were observed on the gel. A comparable northern blot of total RNA from AnFBV-infected $N$. benthamiana and Angelonia revealed the presence of a 3.96-kb RNA when probed with an AnFBV CPspecific DIG-labeled probe (Fig. 4B, lanes 3 and 4). A similar sized RNA was observed by northern blot analysis of AnFBV viral RNA (Fig. 4B, lane 5). Smaller RNAs ranging from 0.93 to $2.59 \mathrm{~kb}$ were also detected in AnFBV-infected $N$. benthamiana and Angelonia plants.

Sequence of the AnFBV genome. The AnFBV genomic RNA is 3,964 nucleotides (GenBank accession no. DQ219415), a size consistent with other carmoviruses $(15,21)$. The RNA contains four ORFs, and $5^{\prime}$ and $3^{\prime}$ untranslated regions (UTRs) of 24 and 257 nucleotides, respectively (Fig. 5). The 5' proximal ORF1 (nucleotides 25 to 759), encodes a 26.8-kDa protein (p27) and terminates with an amber codon which may be read through to generate an $86-\mathrm{kDa}$ protein (p86; nucleotides 25 to 2307). The p86 protein also terminates with an amber codon that may potentially be read through to yield an 87.8-kDa protein (p88; nucleotides 25 to 2349). Two small ORFs, ORF2 and ORF3 (nucleotides 2298 to 2483 and nucleotides 2389 to 2655 , respectively), located in the central part of the viral genome, may encode proteins of $6.7-\mathrm{kDa}$

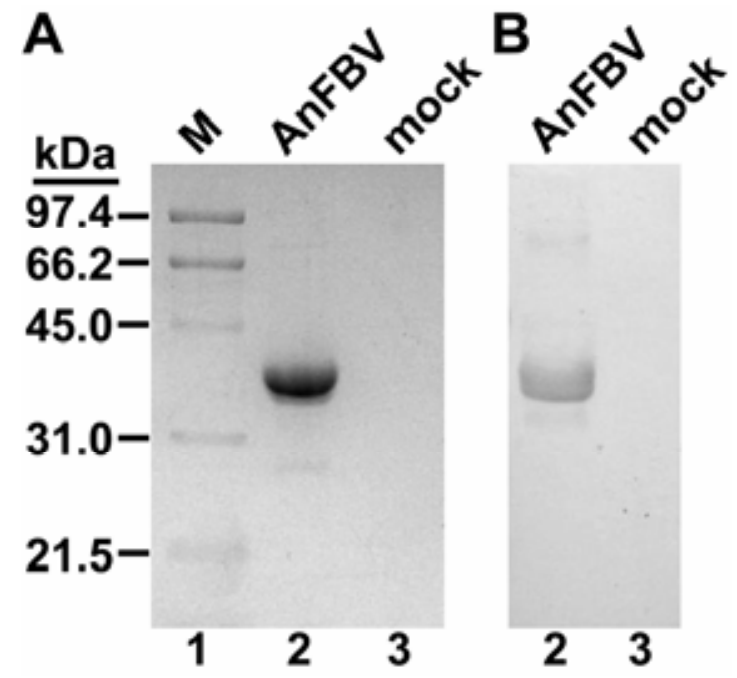

Fig. 3. Sodium dodecyl sulfate-polyacrylamide gel electrophoresis of isolated Angelonia flower break virus (AnFBV) virions followed by $\mathbf{A}$, staining with Coomassie brilliant blue or $\mathbf{B}$, western blotting of a replicate gel probed with immunoglobulin G against AnFBV (diluted 1:2,000). Lane 1, markers (M), lane 2, AnFBV; and lane 3, control preparation (mock). (p7) and 9.7-kDa (p10), respectively. The $3^{\prime}$ proximal ORF4 (nucleotides 2652 to 3707 ) encodes the $38-\mathrm{kDa} \mathrm{CP}$ (or p38), in agreement with SDS-PAGE estimates from purified virions.

The nucleotide and deduced amino acid sequences of the AnFBV CP and replicase were compared with those of various carmovirus species. The AnFBV CP nucleotide and deduced amino acid sequence exhibited 34 to $48 \%$ and 19 to $37 \%$ identities, respectively, with the sequences of other carmoviruses (Table 1). On the other hand, the AnFBV replicase nucleotide and deduced amino acid sequences had identity percentages ranging from 44 to $57 \%$ and 36 to $55 \%$, respectively (Table 2). The highest overall $\mathrm{CP}$ and replicase nucleotide and amino acid identities were obtained with PFBV. The Florida AnFBV CP gene sequence was more similar to the Israeli sequence (98.2\% nucleotide identity; GenBank accession no. DQ223771) than to the Maryland sequence (92.0\% nucleotide identity; GenBank accession no. DQ221212). However, the deduced CP sequences of all three isolates shared a high level of amino acid identity (96.6 to 98.9\%).

Multiple alignments with the sequences of the different carmovirus $\mathrm{CP}$ and replicases were generated and used for phylogenetic analyses. In all cases, AnFBV clustered together with carmoviruses (Fig. 6). The only sequences producing significant alignments from BLASTX queries were those of PFBV and CarMV. However, during review of this manuscript, the $\mathrm{CP}$ sequence of a similar carmovirus isolated from Angelonia in Germany and tentatively named Angelonia flower mottle virus (AnFMV) was released (31).
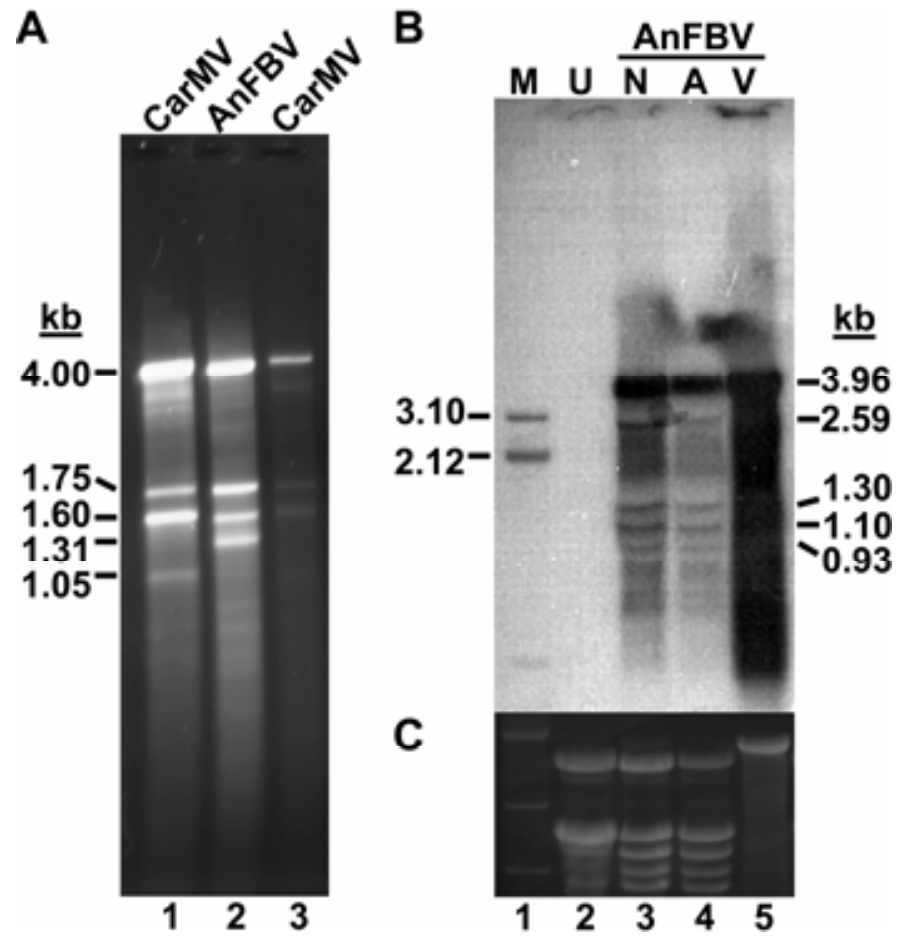

Fig. 4. Results of Angelonia flower break virus (AnFBV) characterization by viral-associated double-stranded (ds)RNA analysis and northern blotting are consistent with its designation as a carmovirus. A, AnFBV dsRNA comigrates with Carnation mottle virus (CarMV) dsRNA. DsRNAs were isolated from leaves of CarMV-inoculated Dianthus spp. (lane 1) or Chenopodium quinoa (lane 3), or AnFBV-inoculated Nicotiana benthamiana (lane 2 ), analyzed by native gel electrophoresis on a $1.5 \%$ agarose gel and stained with ethidium bromide. B, Northern blot analysis of total RNA extracts using an AnFBV coat protein gene probe. Samples of uninoculated $N$. benthamiana (U, lane 2), AnFBV-infected N. benthamiana (N, lane 3), Angelonia (A, lane 4 ), or AnFBV virions ( $\mathrm{V}$, lane 5) were analyzed by denaturing (glyoxal) gel electrophoresis on a $1.2 \%$ agarose gel, transferred to Nytran membrane and probed. Sizes of genomic, subgenomic, and marker (m) RNAs are indicated in kilobases (kb). C, Ethidium bromide-stained gel prior to blotting (B). 


\section{DISCUSSION}

AnFBV was found to be similar to other carmoviruses in particle size and morphology, the apparent molecular mass of the $\mathrm{CP}$, genome organization, and the nucleotide and predicted amino acid sequences of the different genes. Like many carmoviruses, AnFBV caused flower break and mild foliar symptoms in its natural host (Fig. 1) and has a relatively narrow range of experimental hosts. Attempts to find alternative symptomatic hosts for AnFBV have so far failed. The experimental host range was limited to Nicotiana species, Schizanthus pinnatus, Myosotis sylvatica, Phlox drummondii, and Digitalis purpurea. No consistent symptoms were observed despite the high virus yields obtained from $N$. benthamiana. Attempts to passage the virus by aphids to Angelonia or $N$. clevelandii were unsuccessful. No visible symptoms were observed in seedlings grown from seed harvested from AnFBV-infected Angelonia plants up to 2 months after germination, and none of the seedlings were infected with AnFBV as confirmed by ELISA. These results indicate that AnFBV is not seedborne in Angelonia with high efficiency.

AnFBV can be purified directly from Angelonia leaves (Fig. 2D) and from mechanically inoculated $N$. benthamiana leaves (Fig. 2A and B). Purified virus preparations were infectious to both Angelonia and $N$. clevelandii by mechanical inoculation. The
$\mathrm{Mr}$ of $38 \mathrm{kDa}$ observed in SDS-PAGE for the CP (Fig. 3A) was in agreement with those published for other carmoviruses, including PFBV (33 to $37 \mathrm{kDa}$ ), CarMV (37.8 kDa), Hibiscus chlorotic ringspot virus $(44.1 \mathrm{kDa})$, and $\mathrm{SgCV}(38.9 \mathrm{kDa})(4,9,21)$, and with estimates from our sequence data (Fig. 5).

Serological reactions in western blot and decoration tests with AnFBV antisera were very specific and gave clear and strong reactions with the polypeptide corresponding to the $\mathrm{CP}$ (Figs. 2D and $3 \mathrm{~B}$ ). The antiserum did not react with the carmoviruses PFBV, SgCV, and CarMV in either ELISA or western blot assays. Furthermore, antisera against $\mathrm{PFBV}, \mathrm{SgCV}$, and CarMV reacted with the homologous virus but not with AnFBV, indicating that these viruses are serologically distinct.

Sequence analysis of AnFBV isolates from Florida, Maryland, and Israel showed a high degree of similarity in the CP coding region. The Florida AnFBV CP gene sequence is more similar to the Israeli sequence (98.2\% nucleotide identity) than to the Maryland sequence ( $92.0 \%$ nucleotide identity) suggesting a common origin (geographic and/or cultivar) for the Florida and Israeli isolates and a distinct origin for the Maryland isolate. However, the deduced CP sequences of all three isolates share a high level of amino acid identity (96.6 to $98.9 \%$ ). The deduced CP sequence of AnFMV (31) also shares a high level of amino acid identity (97 to $98 \%$ ) with the CPs of the three AnFBV isolates reported here, suggesting that these are the same virus.

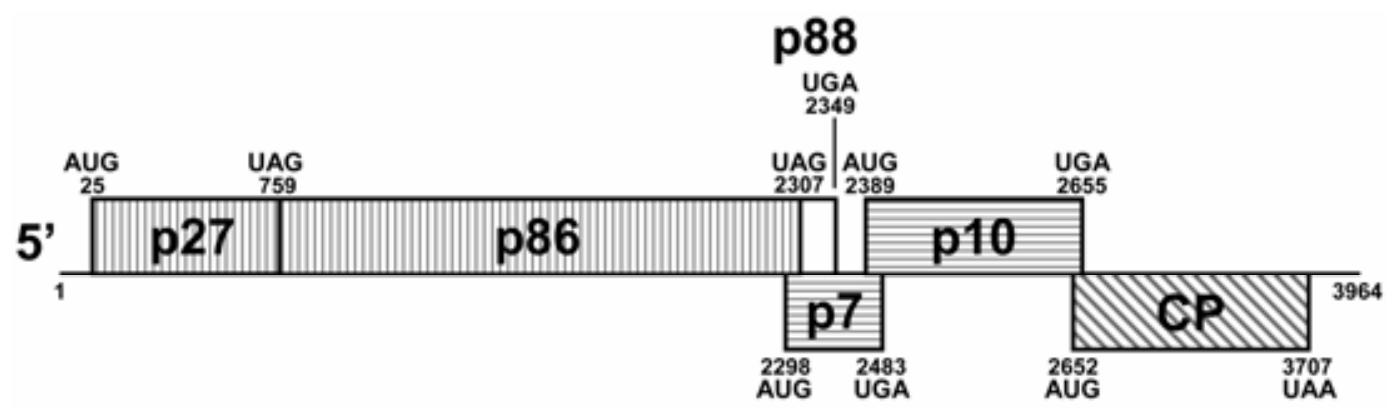

Fig. 5. Genome organization of Angelonia flower break virus. The genomic RNA is shown as a solid line with its size (in nucleotides) indicated. Predicted open reading frames (ORFs) are shown as boxes, with labels inside or above the boxes indicating the polypeptide encoded. Numbers and nucleotide triplets shown above or below ORFs define their start/stop sites. Putative function is denoted by shading with vertical lines for RNA replication (p27, p86), horizontal lines for movement (p7, p10), and diagonal lines for capsid (CP). A second potential readthrough replicase protein (p88) is shown unshaded.

TABLE 1. Amino acid and nucleotide sequence homology (percent identity) between the coat protein gene of Angelonia flower break virus (AnFBV) strains and related carmoviruses

\begin{tabular}{|c|c|c|c|c|c|c|c|c|c|c|c|c|c|c|c|c|}
\hline \multirow[b]{2}{*}{$\underline{\text { Virus }}$} & \multicolumn{16}{|c|}{ Percent identity ${ }^{\mathrm{a}}$} \\
\hline & $\begin{array}{c}\text { AnFBV } \\
\text {-FL }\end{array}$ & $\begin{array}{c}\text { AnFBV } \\
\text {-MD }\end{array}$ & $\begin{array}{c}\text { AnFBV } \\
\text {-IS }\end{array}$ & PFBV & CarMV & ELV & $\mathrm{SgCV}$ & TCV & $\mathrm{CClFV}$ & HCRSV & JINRV & GaMV & CPMoV & PSNV & MNSV & PVM \\
\hline AnFBV-FL & & 97.4 & 98.9 & 36.5 & 33.4 & 29.4 & 30.6 & 25.6 & 25.5 & 27.8 & 28.7 & 23.9 & 18.8 & 22.6 & 20.9 & 9.3 \\
\hline AnFBV-IS & 98.2 & 92.4 & $\ldots$ & 36.5 & 33.4 & 29.1 & 30.6 & 25.1 & 24.9 & 27.8 & 28.4 & 23.9 & 18.8 & 22.6 & 20.6 & 9.3 \\
\hline PFBV & 47.6 & 48.2 & 48.3 & $\ldots$ & 37.6 & 31.2 & 45.5 & 27.3 & 29.1 & 31.4 & 30.1 & 22.5 & 21.8 & 21.4 & 21.0 & 9.5 \\
\hline CarMV & 45.1 & 45.3 & 45.4 & 51.5 & & 33.7 & 41.2 & 27.4 & 27.6 & 31.8 & 28.2 & 25.1 & 23.4 & 22.4 & 20.5 & 10.2 \\
\hline $\mathrm{CClFV}$ & 43.8 & 43.8 & 42.5 & 42.0 & 40.8 & 37.5 & 41.0 & 56.0 & $\ldots$ & 34.5 & 37.9 & 24.8 & 24.3 & 20.6 & 22.9 & 8.7 \\
\hline HCRSV & 39.6 & 39.6 & 39.5 & 41.5 & 40.1 & 39.8 & 40.0 & 42.7 & 46.1 & $\ldots$ & 30.1 & 27.9 & 25.6 & 22.4 & 22.2 & 9.2 \\
\hline JINRV & 38.7 & 38.6 & 38.1 & 37.8 & 39.6 & 37.9 & 39.3 & 44.8 & 47.1 & 43.2 & $\ldots$ & 26.4 & 27.8 & 20.6 & 21.7 & 10.3 \\
\hline GaMV & 37.5 & 37.3 & 36.9 & 38.5 & 38.2 & 36.7 & 37.5 & 39.2 & 38.8 & 40.1 & 38.6 & $\ldots$ & 24.6 & 24.7 & 28.7 & 7.7 \\
\hline CPMoV & 36.3 & 35.5 & 36.5 & 37.9 & 35.3 & 34.0 & 34.6 & 38.3 & 37.8 & 40.7 & 38.6 & 36.4 & $\ldots$ & 19.4 & 19.6 & 6.9 \\
\hline PSNV & 35.1 & 34.9 & 35.1 & 35.4 & 36.4 & 33.7 & 34.1 & 36.9 & 36.7 & 38.1 & 37.1 & 41.4 & 35.3 & & 36.1 & 6.2 \\
\hline
\end{tabular}

a Amino acid identities (above the diagonal) and nucleotide identities (below the diagonal) were calculated using CLUSTALDIST based on ClustalW alignments. Sources of sequences and GenBank accession numbers are as follows: AnFBV-FL, -MD, and -IS (DQ219415, DQ221212, and DQ223771); Pelargonium flower break virus (PFBV; AJ514833); Carnation mottle virus (CarMV; AF192772); Elderberry latent virus (ELV; AY038066); Saguaro cactus virus (SgCV; U72332); Turnip crinkle virus (TCV; M22445); Cardamine chlorotic fleck virus (CClFV; L16015); Hibiscus chlorotic ringspot virus (HCRSV; X86448); Japanese iris necrotic ringspot virus (JINRV; D86123); Galinsoga mosaic virus (GaMV; Y13463); Cowpea mottle virus (CPMoV; U20976); Pea stem necrosis virus (PSNV; AB086951); Melon necrotic spot virus (MNSV; M29671); and Potato virus M (PVM; D14449). 
Several features of the analysis indicate that AnFBV is most closely related to, but distinct from, PFBV. Guidelines for demarcation of virus species cannot be exactly defined and have to be established for each virus genus or family (29). In the plant virus families Geminiviridae and Potyviridae, isolates with less than 85 to $90 \%$ nucleotide identity over the entire genome would normally be regarded as distinct virus species (29); these criteria are exceeded substantially for the carmoviruses most closely related to AnFBV (i.e., PFBV and CarMV; $\approx 57 \%$ in the replicase; 45 to $48 \%$ in the $\mathrm{CP}$ ), indicating that the differences are of an order that separates distinct carmoviruses (24). These sequence identities also exceed the levels reported by Castaño and Hernández (5) for viruses in different genera of the family Tombusviridae, supporting assignment of AnFBV to the genus Carmovirus.

In conclusion, based on particle morphology, the $\mathrm{Mr}$ of the $\mathrm{CP}$ and the genome sequence and organization, it is suggested that AnFBV belongs to the genus Carmovirus. Moreover, the differences in host range, serological reactions, genome sequence, and predicted protein sequence provide sufficient justification to consider AnFBV a novel carmovirus. In pondering a suitable designation for the Angelonia carmovirus, we propose that it be called Angelonia flower break virus (AnFBV) to designate the natural host of the virus and the most prominent symptom it incites on this host.

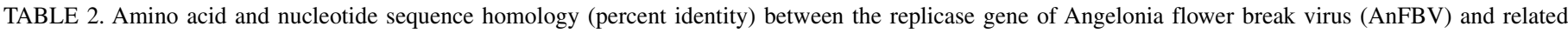
carmoviruses

\begin{tabular}{|c|c|c|c|c|c|c|c|c|c|c|c|c|c|}
\hline \multirow[b]{2}{*}{ Virus } & \multicolumn{13}{|c|}{ Percent identity ${ }^{\mathrm{a}}$} \\
\hline & AnFBV & PFBV & CarMV & $\mathrm{SgCV}$ & HCRSV & $\mathrm{TCV}$ & PSNV & MNSV & $\mathrm{CClFV}$ & JINRV & CPMoV & GaMV & PVM \\
\hline AnFBV-FL & $\ldots$ & 54.5 & 51.8 & 51.5 & 43.5 & 42.4 & 42.0 & 41.8 & 41.0 & 40.6 & 39.5 & 35.6 & 13.9 \\
\hline PFBV & 56.9 & $\ldots$ & 57.7 & 55.9 & 43.3 & 42.0 & 42.3 & 42.0 & 41.2 & 39.7 & 39.8 & 34.5 & 12.8 \\
\hline CarMV & 56.5 & 59.7 & $\ldots$ & 53.3 & 41.3 & 41.6 & 39.4 & 41.1 & 42.4 & 40.4 & 37.3 & 38.4 & 13.0 \\
\hline $\mathrm{SgCV}$ & 55.3 & 57.1 & 54.5 & $\ldots$ & 42.9 & 41.2 & 40.7 & 41.4 & 39.9 & 40.0 & 38.7 & 34.4 & 12.3 \\
\hline HCRSV & 48.4 & 50.2 & 47.7 & 49.3 & $\ldots$ & 55.2 & 45.8 & 43.0 & 56.0 & 52.2 & 43.0 & 36.0 & 13.1 \\
\hline $\mathrm{TCV}$ & 47.9 & 48.3 & 48.7 & 47.5 & 53.5 & $\ldots$ & 42.9 & 43.2 & 67.7 & 48.5 & 44.4 & 35.8 & 13.9 \\
\hline PSNV & 48.0 & 47.8 & 46.9 & 47.9 & 50.8 & 48.6 & ... & 57.2 & 48.1 & 45.8 & 48.6 & 48.3 & 13.1 \\
\hline MNSV & 46.5 & 47.9 & 47.1 & 46.0 & 48.2 & 48.1 & 60.3 & $\ldots$ & 48.0 & 45.8 & 48.9 & 47.1 & 11.6 \\
\hline $\mathrm{CClFV}$ & 47.7 & 49.0 & 48.7 & 46.4 & 51.8 & 68.4 & 42.9 & 44.7 & $\ldots$ & 46.8 & 42.3 & 34.9 & 13.2 \\
\hline JINRV & 47.3 & 46.9 & 47.2 & 46.9 & 48.9 & 51.8 & 41.6 & 39.0 & 52.1 & $\ldots$ & 38.3 & 33.7 & 12.3 \\
\hline CPMoV & 47.3 & 47.0 & 48.4 & 47.0 & 51.9 & 50.2 & 42.6 & 42.7 & 49.9 & 53.5 & $\ldots$ & 36.0 & 12.3 \\
\hline GaMV & 44.1 & 44.2 & 44.2 & 44.2 & 46.2 & 45.2 & 39.4 & 38.9 & 46.4 & 45.6 & 47.1 & $\ldots$ & 11.5 \\
\hline PVM & 32.1 & 32.0 & 32.4 & 33.0 & 36.4 & 38.3 & 35.5 & 36.1 & 34.5 & 32.8 & 33.7 & 34.3 & $\ldots$ \\
\hline
\end{tabular}

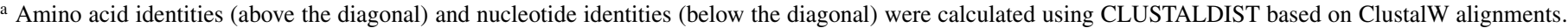
Sources of sequences and GenBank accession numbers are as follows: AnFBV-FL (DQ219415), Pelargonium flower break virus (PFBV; AJ514833), Carnation mottle virus (CarMV; AF192772), Saguaro cactus virus (SgCV; U72332), Hibiscus chlorotic ringspot virus (HCRSV; X86448), Turnip crinkle virus (TCV; M22445), Pea stem necrosis virus (PSNV; AB086951), Melon necrotic spot virus (MNSV; M29671), Cardamine chlorotic fleck virus (CClFV; L16015), Japanese iris necrotic ringspot virus (JINRV; D86123), Cowpea mottle virus (CPMoV; U20976), Galinsoga mosaic virus (GaMV; Y13463), and Potato virus M (PVM; D14449).
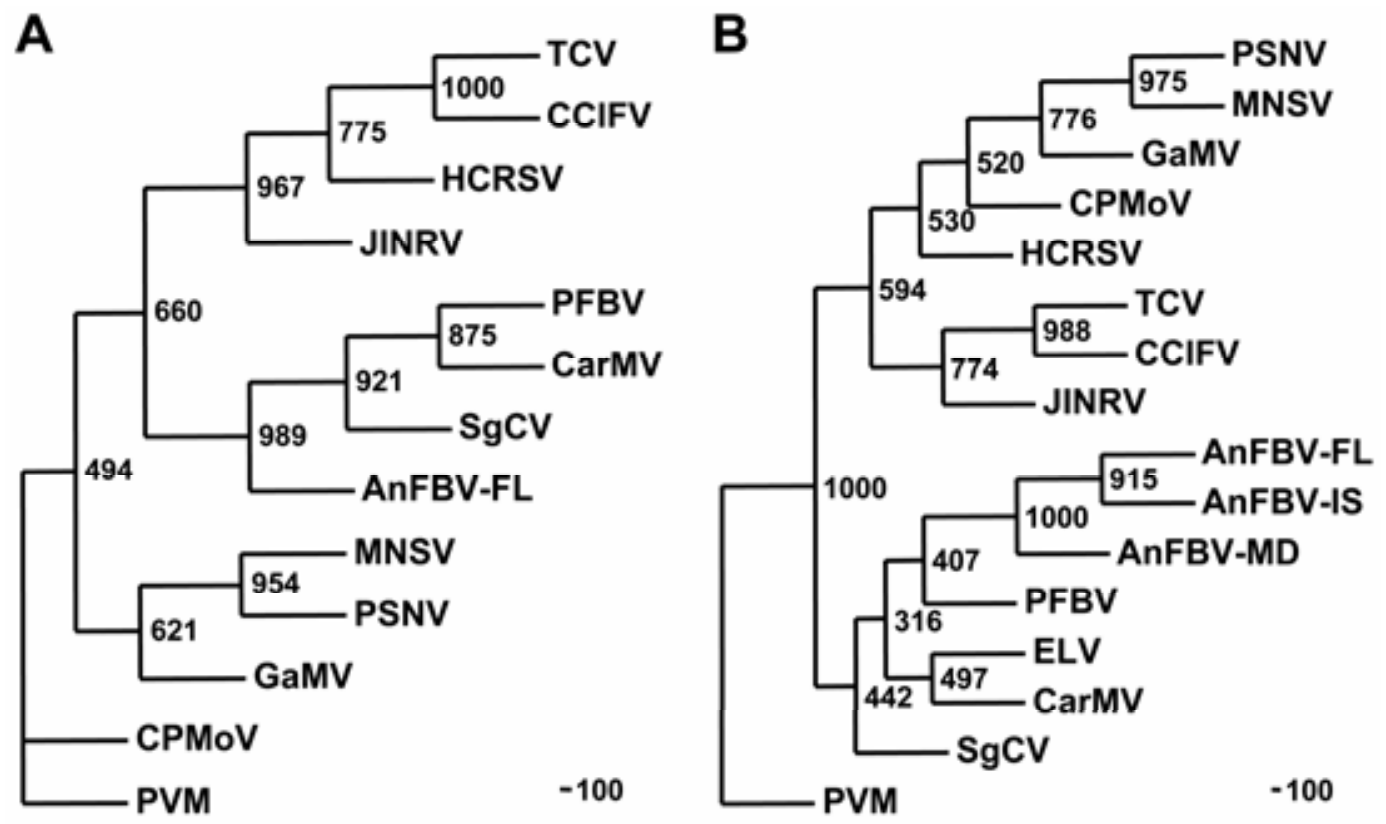

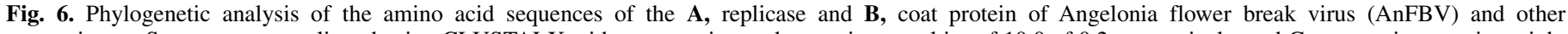

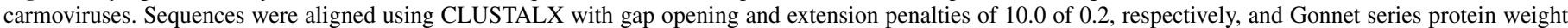

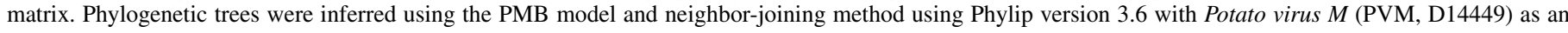

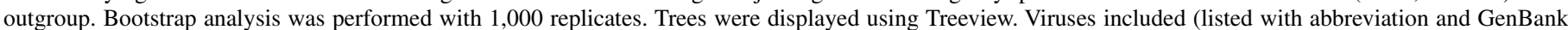

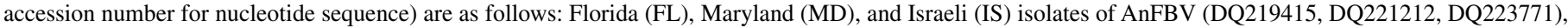

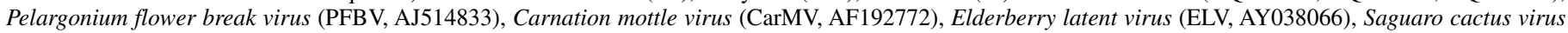

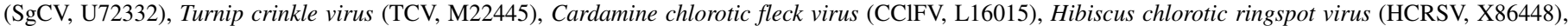

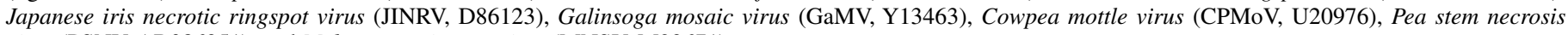
virus (PSNV, AB086951), and Melon necrotic spot virus (MNSV, M29671). 


\section{ACKNOWLEDGMENTS}

We thank C. Vanderspool, S. Clark, H. Barber, M. Reinsel, and S. Jhingory for excellent technical assistance; D. Achor and M. Dienelt for electron microscopy; and J. Vandermeij, D. Thomas, M. Tiffany, M. Bandla, and C. Sutula for valuable discussions.

\section{LITERATURE CITED}

1. Altschul, S. F., Madden, T. L., Schäffer, A. A., Zhang, J., Zhang, Z., Miller, W., and Lipman, D. J. 1997. Gapped BLAST and PSI-BLAST: A new generation of protein database search programs. Nucleic Acids Res. 25:3389-3402.

2. Bar Joseph, M., Gumpf, D. J., Dodds, J. A., Rosner, A., and Ginzberg, I. 1985. A simple purification method for citrus tristeza virus and estimation of its genome size. Phytopathology 75:195-198.

3. Brunt, A. A. 1995. Pages 29-66 in: Viruses and Virus-Like Diseases of Bulb and Flower Crops. G. Loebenstein, R. H. Lawson, and A. A. Brunt, eds. John Wiley \& Sons, Chichester.

4. Brunt, A. A., Crabtree, K., Dallwitz, M. J., Gibbs, A. J., and Watson, L. 1996. Viruses of Plants: Descriptions and Lists from the VIDE Database. CAB International, UK.

5. Castaño, A., and Hernández, C. 2005. Complete nucleotide sequence and genome organization of Pelargonium line pattern virus and its relationship with the family Tombusviridae. Arch. Virol. 150:949-965.

6. Chang, S., Puryear, J., and Cairney, J. 1993. A simple and efficient method for isolating RNA from pine trees. Plant Mol. Biol. Rep. 11:113-116.

7. Clark, M. F., and Adams, A. N. 1977. Characteristics of the microplate method of enzyme-linked immunosorbent assay (ELISA) for the detection of plant viruses. J. Gen. Virol. 34:475-483.

8. Felsenstein, J. 1989. PHYLIP-Phylogeny Inference Package. Version 3.2. Cladistics 5:64-166.

9. Franck, A., and Loebenstein, G. 1994. Virus and virus-like diseases of pelargonium in Israel. Acta Hortic. 377:31-39.

10. Gera, A., Loebenstein, G., Salomon, R., and Franck, A. 1990. An inhibitor of virus replication (NR) from protoplasts of a hypersensitive tobacco cultivar infected with tobacco mosaic virus is associated with a $23 \mathrm{~K}$ protein species. Phytopathology 80:78-81.

11. Hammond, J., and Lawson, R. H. 1988. An improved purification procedure for preparing potyviruses and cytoplasmic inclusion proteins from the same tissue. J. Virol. Methods 20:203-217.

12. Jordan, R., and Hammond, J. 1991. Comparison and differentiation of potyvirus isolates and identification of strain-, virus-, subgroup-specific and potyvirus group-common epitopes using monoclonal antibodies. J. Gen. Virol. 72:25-36.

13. Jordan, R. L., Dodds, J. A., and Ohr, H. D. 1983. Evidence for viruslike agents in avocado. Phytopathology 73:1130-1135.

14. Lawson, R. H., Brannigan, M. D., and Foster, J. 1985. Clover yellow vein virus in Limonium sinuatum. Phytopathology 75:899-906.

15. Lommel, S. A., Martelli, G. P., Rubino, L., and Russo, M. 2005. Pages 922-926 in: Virus Taxonomy-Classification and Nomenclature of Viruses, 8th Report of the ICTV. C. M. Fauquet, M. A. Mayo, J. Maniloff, U. Desselberger, and L. A. Ball, eds. Elsevier Academic Press, San Diego.

16. Liu, H.-Y., Sears, J. L., and Morrison, R. H. 2003. Isolation and characterization of a carmo-like virus from Calibrachoa plants. Plant Dis. 87:167-171.

17. Milne, R. G., and Luisoni, E. 1975. Rapid high-resolution immune electron microscopy of plant viruses. Virology 68:270-274.

18. Navas-Castillo, J., Albiach-Marti, M. R., Gowda, S., Hilf, M. E., Garnsey, S. M., and Dawson, W. O. 1997. Kinetics of accumulation of citrus tristeza virus RNAs. Virology 228:92-97.

19. Orion, D., and Franck, A. 1990. An electron microscopy study of cell wall lysis by Meloidogyne javanica gelatinous matrix. Rev. Nematol. 13:105107.

20. Page, R. D. M. 1996. TREEVIEW: An application to display phylogenetic trees on personal computers. Computer Appl. Biosci. 12:357-358

21. Rico, P., and Hernández, C. 2004. Complete nucleotide sequence and genome organization of Pelargonium flower break virus. Arch. Virol. 149:641-651.

22. Sambrook, J., and Russell, D. W. 2001. Molecular Cloning: A Laboratory Manual. 3rd ed. Cold Spring Harbor Laboratory, Cold Spring Harbor, NY.

23. Schoellhorn, R. 2002. Angelonia, the warm season snapdragon. Greenhouse Product News. 12:77-78.

24. Stuart, G., Moffett, K., and Bozarth, R. F. 2004. A whole genome perspective on the phylogeny of the plant virus family Tombusviridae. Arch. Virol. 149:1595-1610.

25. Thompson, J. D., Gibson, T. J., Plewniak, F., Jeanmougin, F., and Higgins, D. G. 1997. The ClustalX Windows interface: Flexible strategies for multiple sequence alignment aided by quality analysis tools. Nucleic Acids Res. 24:4876-4882.

26. Thompson, J. D., Higgins, D. G., and Gibson, T. J. 1994. CLUSTAL W: Improving the sensitivity of progressive multiple sequence alignment through sequence weighting, position-specific gap penalties and weight matrix choice. Nucleic Acids Res. 22:4673-4680.

27. Towbin, H., Staehelin, T., and Gordon, J. 1979. Electrophoretic transfer of proteins from polyacrylamide gels to nitrocellulose sheets: Procedure and some applications. Proc. Natl. Acad. Sci. USA 76:4350-4354.

28. Valverde, R. A., Nameth, S. T., and Jordan, R. L. 1990. Analysis of double-stranded RNA for plant virus diagnosis. Plant Dis. 74:255-258.

29. Van Regenmortel, M. H. V., Bishop, D. H. L., Fauquet, C. M., Mayo, M. A., Maniloff, J., and Calisher, C. H. 1997. Guidelines to the demarcation of virus species. Arch. Virol. 142:1505-1518.

30. Waterworth, H. E., Lawson, R. H., and Monroe, R. L. 1976. Purification and properties of hibiscus chlorotic ringspot virus. Phytopathology 66:570-575

31. Winter, S., Hamacher, A., Engelmann, J., and Lesemann, D.-E. 2006. Angelonia flower mottle, a new disease of Angelonia angustifolia caused by a hitherto unknown carmovirus. New Disease Reports. Published online by the British Society for Plant Pathology. http://www.bspp.org.uk/ ndr/jan2006/2005-82.asp.

32. Zeidan, M., Cohen, J., Watad, A., and Gera, A. 1998. Improved purification and molecular properties of Ornithogalum mosaic virus in Israel. Ann. Appl. Biol. 133:167-176. 